\title{
Meaning of Life Siswa Sekolah Menengah Pertama dengan Latar Belakang Budaya Samin
}

\author{
Maghfirotul Amalia, Nur Hidayah, Lutfi Fauzan \\ Jurusan Bimbingan dan Konseling, Fakultas Ilmu Pendidikan, Universitas Negeri Malang, \\ Jl. Semarang No. 5, Malang, Jawa Timur, Indonesia 65145 \\ E-mail: amalia_maghfirotul@yahoo.com
}

Artikel diterima: 4 Juni 2017; direvisi 15 September 2017; disetujui 24 September 2017

\begin{abstract}
This study aims to describe the junior high school students with Samin cultural background's meaning of life of that comes from: creative values, experiential values and attitudinal values. This study follows the steps of survey types in a descriptive quantitative approach. The instruments used are developed in inventory. Data were analyzed by using descriptive analysis technique and SPSS 20.0 for Windows in order to determine the frequency, percentage, standard deviation, skewness. Results show that junior high school students with Samin cultural background was able to find the meaning of life through three sources of value, which experiential values reach the highest percentage (45\%) followed by attitudinal value (29\%), and the creative value (26\%). In particular, these results illustrate that the fulfillment of meaning of life of junior high school students with a cultural background of Samin is in accordance with the Samin culture which prioritizes appreciation of the values of life before acting and responding to something.
\end{abstract}

Keywords: meaning of life; sources of value; Samin culture; junior high school students

\begin{abstract}
Abstrak: Penelitian ini bertujuan untuk mendeskripsikan meaning of life siswa sekolah menengah pertama dengan latar belakang budaya Samin yang bersumber dari: creative values, experiential values dan attitudinal values. Penelitian ini menggunakan langkahlangkah dalam pendekatan kuantitatif deskriptif jenis survei. Instrumen yang digunakan, dikembangkan dalam bentuk inventori. Teknik analisis data menggunakan analisis deskriptif untuk menentukan frekuensi, persentase, standar deviasi, skewness, dengan bantuan program SPSS 20.0 for windows. Hasil menunjukkan bahwa siswa sekolah menengah pertama dengan latar belakang budaya Samin mampu menemukan meaning of life melalui tiga sumber nilai, dengan experiential values menduduki persentase tertinggi (45\%), diikuti attitudinal values $(29 \%)$, dan creative values (26\%). Secara khusus, hasil ini menggambarkan bahwa pemenuhan meaning of life siswa sekolah menengah pertama dengan latar belakang budaya Samin sesuai dengan budaya Samin yang mengutamakan penghayatan terhadap nilai-nilai kehidupan sebelum bertindak dan menyikapi sesuatu.
\end{abstract}

Kata kunci: meaning of life; sumber nilai; budaya Samin; siswa sekolah menengah pertama

Hidup dan kehidupan merupakan dua hal yang tidak bisa dipisahkan dalam diri manusia. Kehidupan adalah suatu cara dalam menikmati proses hidup, di dalam proses mewujudkan kehidupan terdapat keinginan-keinginan tertentu seperti: keinginan untuk menjadi pribadi yang berguna, berharga bagi diri sendiri, keluarga, maupun lingkungan masyarakat. Keinginan-keinginan ini ternyata menggambarkan hasrat yang paling mendasar manusia, yaitu hasrat untuk menemukan meaning of life (Bastaman, 2005)

Teori-teori tentang meaning of life yang berkembang pada dasarnya diilhami oleh dua teori pokok milik Frankl dan Maslow. Frankl dalam Sumanto (2006), dengan teori Logoterapi memahami 
meaning of life sebagai proses penemuan isi dunia sekitar yang bermakna intrinsik secara individual. Kerangka pikir teori ini juga menyatakan bahwa kebahagiaan ternyata tidak terjadi begitu saja tetapi merupakan hasil dari keberhasilan seseorang menemukan meaning of life. Menurut Frankl dalam Bastaman (2005), meaning of life dapat dicapai individu melalui tiga sumber nilai yaitu: creative values, experiential values dan attitudinal values.

Berbeda dengan Frankl, meaning of life dalam teori yang dikemukakan Abraham Maslow adalah suatu sifat yang muncul dari dalam diri seseorang. Maslow dalam Sumanto (2006), berpendapat bahwa meaning of life berasal dari dalam diri individu yang berkembang sebagai proses aktualisasi diri. Tentunya hal ini berbeda dengan Frankl yang menekankan bahwa meaning of life merupakan proses pencarian, bukan berasal dari dalam diri seseorang. Meskipun ada perbedaan secara teoritis, kedua teori ini memiliki kesamaan atau kesepakatan bahwa keputusasaan, kecemasan, depresi, dan kekerasan, merupakan hasil dari munculnya eksistensi hampa (hidup tidak bermakna).

Eksistensi hampa merupakan persoalan yang akhir-akhir ini menjadi tantangan. Merujuk dalam pandangan Frankl bahwa meaning of life merupakan pencarian bukan diciptakan maka permasalahan yang sering muncul adalah tidak semua orang mampu menemukan meaning of life. Cohen \& Chairns dalam Setyarini \& Atamimi (2011), menyatakan bahwa tingginya pencarian makna hidup dan rendahnya kemunculan makna hidup, dapat mengakibatkan depresi. Sementara itu, hasil survei terhadap 800 responden remaja berusia 15-22 tahun di Jakarta, Yogyakarta, Medan, Surabaya, dan Makassar, memperlihatkan bahwa remaja Indonesia cenderung bersikap apolitis dan apatis terhadap keadaan (Gatra dalam Alfian \& Suminar, 1999). Fenomena ini merupakan contoh dari sindrom ketidakbermaknaan dalam hidup remaja di Indonesia, yaitu frustrasi eksistensial.

Frankl dalam Koeswara (1992), menandai adanya dua tahapan pada sindrom ketidakbermaknaan dalam hidup, yaitu frustasi eksistensial dan noogenic neurosis. Frustasi eksistensial salah satunya disebabkan karena kehilangan tradisi yang mengakibatkan manusia kehilangan dukungan dan bimbingan moral sehingga tidak lagi memiliki kepastian tentang apa yang sepatutnya diperbuat (Koeswara, 1992). Apabila kondisi ini dialami oleh banyak orang maka tidak diragukan lagi hasilnya adalah suatu keadaan masyarakat carut marut yang jika dibiarkan dapat menghasilkan manusiamanusia kriminal, koruptor, peminum, pecandu narkotik, bahkan orang yang membunuh dirinya sendiri (Frankl, 2003).

Kasus bunuh diri di kalangan remaja Indonesia telah menunjukkan angka yang mengkhawatirkan. Catatan laboratorium psikiatri Fakultas Kedokteran Universitas Airlangga, dari tahun 1983-1985 menunjukkan angka bunuh diri di kalangan remaja usia 11-20 tahun berjumlah 312 orang yang terdiri dari 239 orang wanita dan 73 pria (Alfian \& Suminar, 1999). Fenomena ini adalah contoh dari frustasi eksitensial yang ditandai dengan gejala neurotik klinis, yang disebut Frankl sebagai noogenic neurosis (Koeswara, 1992). Oleh karena itu, penelitian mengenai meaning of life banyak dilakukan dalam beberapa dekade terakhir. Penelitian tersebut antara lain oleh Setyarini \& Atamimi (2011), mengenai faktor yang terkait eksplorasi makna hidup serta hubungannya dengan hasil perkembangan positif, tingkat kebermaknaan hidup pada lansia (Rohmah, 2011) dan makna hidup pada wanita yang berperan ganda (Putri, 2009).

Meaning of life kemudian menjadi suatu hal yang menarik untuk dikaji, terlebih meaning of life dari kelompok remaja yang memiliki tradisi budaya dan terrepresentasikan pada tingkah laku, perasaan, bahkan cara pandang terhadap kehidupan. Hal ini menarik manakala remaja dinilai telah mampu mempertanyakan meaning of life secara sosial yang diserap melalui kehidupan pribadinya (Sumanto, 2006).

Indonesia memiliki banyak suku dan budaya yang menarik untuk dikaji lebih jauh mengenai cara mereka memaknai kehidupan. Salah satu contohnya adalah siswa dengan latar budaya Samin. Mengkaji meaning of life remaja dengan latar belakang budaya Samin ini menarik karena adanya keteguhan dan kepatuhan mereka dalam hal memaknai kehidupan berdasarkan nilai-nilai dalam tradisi yang diajarkan oleh leluhurnya. Hampir sama dengan siswa dengan latar budaya Samin, 
Siswa SMP etnis Tengger yang memegang teguh kebudayaan mereka ternyata memiliki meaning of life yang tinggi (Ningsih, Hidayah, \& Lasan, 2017). Hal tersebut terjadi karena pengaruh agama dan budayanya.

Meningkatnya taraf pendidikan dari para remaja dengan latar belakang budaya Samin, secara tidak langsung berdampak pada kelenturan identitas Samin. Namun, bukan berarti secara keseluruhan nilai dalam ajaran budaya Samin ini berubah bahkan hilang. Melainkan, ajaran tetap dipertahankan karena dinilai masih sesuai dengan keyakinan agama yang dianut. Ajaran yang masih dipertahankan dan menjadi bimbingan moral remaja dengan latar belakang budaya Samin adalah Serat Uri-uri Pambudi (Syam, 2007).

Ajaran budaya Samin dalam Serat Uri-uri Pambudi dapat digolongkan pada sumber nilai yang dikemukakan oleh Viktor Frankl dalam memenuhi meaning of life. Sehingga, secara tidak langsung sumber nilai yang terkandung dalam ajaran Serat Uri-uri Pambudi ini memengaruhi bagaimana remaja dengan latar belakang budaya Samin, khususnya yang tengah menempuh pendidikan pada jenjang Sekolah Menengah Pertama (SMP) dalam menjalani kehidupan. Oleh karena itu, diperlukan sebuah layanan pendidikan yang mampu menjembatani cara pandang siswa SMP dengan latar belakang budaya Samin yang mampu mengarahkan dan memfasilitasi mereka mengambil keputusan dalam hidupnya.

Bimbingan dan konseling adalah sebuah layanan yang dapat memfasilitasi siswa untuk mengembangkan diri melalui pemenuhan meaning of life dalam konteks budaya siswa. Karena dengan pemenuhan meaning of life maka individu dapat menjadikannya sebagai pedoman dan tujuan hidup, sehingga kehidupannya dapat terarah dan kebahagiaan dapat dirasakan oleh siswa. Keterkaitan dan keselarasan antara ajaran budaya Samin dengan konsep sumber nilai yang dikemukakan Viktor Frankl digunakan sebagai dasar teori dalam penelitian ini. Alasan digunakan teori ini disebabkan sumber nilai yang dikemukakan oleh Viktor Frankl, dapat mengukur dan mendeskripsikan meaning of life siswa SMP dengan latar belakang budaya Samin di Dusun Jepang, Desa Margomulyo, Kecamatan Margomulyo, Kabupaten Bojonegoro, yang sedang menempuh pendidikan menengah pertama.

\section{METODE}

\section{Rancangan Penelitian}

Penelitian ini menggunakan pendekatan kuantitatif dengan metode deskriptif. Rancangan penelitian deskriptif yang digunakan yakni jenis survei. Jenis data yang diambil dalam penelitian ini adalah data ekspos fakto, sehingga data tersebut merupakan kegiatan atau kejadian yang telah berlangsung atau telah terjadi.

\section{Subjek Penelitian}

Metode pengambilan sampel pada penelitian ini adalah sampel non probabilitas (non probability sampling), di mana setiap unsur dari populasi tidak memiliki kesempatan yang sama untuk dipilih sebagai sampel. Metode ini dipilih karena penelitian tidak bertujuan untuk melakukan generalisasi atas dasar satu sampel. Jenis sampel non probabilitas yang digunakan yakni sampel jenuh atau total. Sampel total adalah metode pengambilan sampel di mana semua anggota populasi sasaran diambil sebagai anggota sampel, yaitu seluruh siswa dengan latar belakang budaya Samin yang sedang menempuh pendidikan SMP dan tinggal di Dusun Jepang, Kecamatan Margomulyo, Kabupaten Bojonegoro, Provinsi Jawa Timur. Sehingga diperoleh sampel total berjumlah 24 siswa.

\section{Instrumen}

Instrumen yang digunakan dikembangkan oleh penulis dalam bentuk inventori. Butir pernyataan dalam inventori disusun dengan panduan kisi-kisi yang didasarkan pada teori meaning of life yang dikemukakan oleh Viktor Frankl. Kisi-kisi dikembangkan menjadi butir pernyataan yang sudah 
teruji validitasnya. Uji validitas dilakukan secara logik dan empirik. Validitas logik pada prinsipnya mencakup validitas isi yang ditentukan oleh pertimbangan para pakar, sedangkan validitas empirik dengan menggunakan formulasi statistik (Sukardi, 2003).

Pada teknik inventori, untuk memudahkan penentuan skor pada hasil inventori, maka digunakan skala Likert. Jawaban pada skala Likert yang digunakan adalah: sangat sesuai (SS); sesuai (S); kurang sesuai (KS); dan tidak sesuai (TS). Teknik penskorannya yaitu: sangat sesuai $=4$; sesuai $=3$; kurang sesuai $=2$; tidak sesuai $=1$. Selanjutnya validitas empirik, dengan menggunakan software SPSS 20.0 for windows. Instrumen penelitian dapat dikatakan valid jika koefisien korelasi product moment pearson $\geq 0,3$ (Sugiyono, 2006), diketahui butir pernyataan valid dan tidak valid. Untuk pernyataan yang tidak valid berjumlah 21 butir yaitu: 14 butir pada sub variabel creative value; 6 butir pada sub variabel experiential values; dan 1 butir pada sub variabel attitudinal value. Butir pernyataan yang tidak valid dapat dihilangkan dengan pertimbangan terdapat butir lain yang mewakili indikator dalam setiap sub variabel.

Reliabilitas digunakan untuk mengetahui sejauh mana hasil pengukuran relatif tetap konsisten apabila dilakukan pengukuran dua kali atau lebih (Masri \& Effendi, 2012). Analisis reliabilitas instrumen menggunakan teknik Alpha Cronbach dengan bantuan program SPSS 20.0 for windows. Instrumen penelitian dikatakan reliabel apabila koefisien reliabilitas $\geq 0.5$ dan reliabilitas yang tinggi jika memiliki nilai koefisien alpha $\geq 0.7$ (Ghozali, 2011). Hasil uji reliabilitas dengan jumlah total 150 butir pernyataan diketahui bahwa nilai reliabilitas sebesar 0.969 . Setelah 21 butir yang tidak memenuhi koefisien reliabilitas dihilangkan, nilai reliabilitas naik sebesar 0.986 .

Secara keseluruhan instrumen penelitian meaning of life siswa SMP dengan latar belakang budaya Samin berdistribusi normal, karena rasio kecondongan bernilai $<-1,96$ yang diperoleh melalui hasil nilai skewness (-0.377) dibagi nilai standart error skewness $(0.472)$. Oleh karena itu, hasil akhir instrumen penelitian dalam bentuk inventori meaning of life siswa SMP dengan latar belakang budaya Samin, berjumlah 129 butir pernyataan yang terdiri dari tiga sub variabel: creative values, experiential values dan attitudinal values. Inventori ini telah memenuhi persyaratan validitas dan reliabilitas instrumen penelitian, sehingga hasil dari pengukuran dapat menggambarkan aspek yang diukur.

\section{Prosedur Pengumpulan Data}

Prosedur pengumpulan data yang digunakan sesuai dengan metode deskriptif jenis survei, yaitu: merumuskan masalah dan menentukan tujuan survei, menentukan konsep dan menggali kepustakaan, mengambil sampel, membuat dan menyusun inventori, melakukan uji lapangan, mengolah data, menganalisis dan melaporkan. Responden merupakan siswa SMP yang dapat membaca dengan baik dan dapat mengungkapkan hal-hal yang sifatnya rahasia. Berdasarkan pertimbangan tersebut, penelitian ini menggunakan teknik pengumpulan data dalam bentuk inventori untuk mengukur meaning of life: creative values, experiential values dan attitudinal values siswa SMP dengan latar belakang budaya Samin.

\section{Analisis Data}

Analisis data yang digunakan menggunakan statistik deskriptif sederhana yang bertujuan untuk memberikan deskripsi mengenai penyajian data penelitian. Hasil analisis dengan statistik deskriptif lazimnya ditampilkan dalam bentuk sebaran data, seperti: jumlah kelas (p), panjang interval kelas, distribusi frekuensi (f), histogram, dan poligon. Sehingga, analisis data yang digunakan adalah statistik deskriptif sederhana untuk menentukan persentase, standar deviasi, frekuensi, dan skewness yang ditampilkan dalam bentuk histogram. Keseluruhan proses analisis data ini menggunakan bantuan program SPSS 20.0 for windows. 


\section{HASIL}

Hasil penelitian menunjukkan bahwa sangat banyak siswa SMP dengan latar belakang budaya Samin yang masuk pada kategori meaning of life tinggi (91.7\%). Kategori meaning of life tinggi juga didasarkan pada persentase standar deviasi yaitu meaning of life (40\%); creative values $(11 \%)$; experiential value (19\%); dan attitudinal values (14\%). Secara keseluruhan, hasil data penelitian dapat dikatakan berdistribusi normal, dengan melihat hasil dari z skewness yang bernilai < 1.96 yaitu: meaning of life $(-0,798)$; creative values $(-1,336)$; experiential value $(-0,654)$; dan attitudinal values $(-0,014)$. Berdasarkan klasifikasi meaning of life, jika seluruh skor pada masing-masing sub variabel dijumlahkan maka diketahui persentase sumber nilai dengan nilai tertinggi adalah experiential values (45\%) yang kemudian diikuti attitudinal values (29\%) dan creative values (26\%). Hasil ini juga disajikan pada tabel 1 .

\section{Tabel 1 Sumber Nilai Meaning of Life}

\begin{tabular}{lcc}
\hline \multicolumn{1}{c}{ Sumber Nilai } & N & \% \\
\hline Nilai Kreatif & 2681 & 26 \\
Nilai Penghayatan & 4611 & 45 \\
Nilai Bersikap & 3003 & 29 \\
\hline
\end{tabular}

\section{PEMBAHASAN}

Hasil penelitian menunjukkan bahwa meaning of life siswa SMP dengan latar belakang budaya Samin tergolong tinggi. Keteguhan dan kepatuhan mereka dalam hal memaknai kehidupan berdasarkan nilai-nilai dalam tradisi yang diajarkan oleh leluhurnya menjadi salah satu penyebab. Ketidakbermaknaan seseorang ditandai dengan frustrasi eksistensial yang salah satunya dikarenakan kehilangan tradisi (Koeswara, 1992). Kehilangan tradisi mengakibatkan individu kehilangan dukungan dan bimbingan moral sehingga tidak lagi memiliki kepastian tentang apa yang sepatutnya diperbuat. Sementara, tradisi dalam budaya Samin hingga saat ini masih dipertahankan dan menjadi bimbingan moral dari setiap generasi. Oleh karena itu, menjadi benar adanya jika meaning of life siswa SMP dengan latar belakang budaya Samin tergolong tinggi, dengan tetap mengacu pada penjelasan Boeree (2010), bahwa meaning of life tidak terikat dengan nilai-nilai masyarakat melainkan setiap masyarakat dapat berusaha mencari kebermaknaan hidup dalam tata aturan dan norma-norma sosial mereka.

Bagian dalam Budaya Samin yaitu: nilai, norma, dan tradisi yang terhimpun dalam ajaran Serat Jamus Kalimusodo. Serat Jamus Kalimusodo berisi lima ajaran kehidupan, dan salah satunya adalah Serat Uri-uri Pambudi. Serat Uri-uri Pambudi dinilai sebagai aturan yang membimbing moral masyarakat Samin sehingga selaras jika dikaitkan dengan sumber nilai meaning of life, terlebih ajaran ini dapat dikaitkan dengan perkembangan generasi muda Samin yang tengah menempuh pendidikan pada jenjang SMP. Kandungan dalam Serat Uri-uri Pambudi terdiri atas tiga hukum dalam mengatur perilaku, yaitu: (1) Angger-angger Pengucap (hukum ucapan); (2) Angger-angger Pertikel (hukum perilaku); dan (3) Angger-angger Lakunana (hukum pelaksanaan).

Angger-angger Pengucap (hukum ucapan), merupakan hukum pertama tentang bagaimana masyarakat Samin dalam berbicara atau bertutur kata dengan orang lain. Hukum pertama ini menjadikan masyarakat Samin memiliki prinsip dalam berbicara jangan waton omong, yen omong nganggo waton, artinya menjadi masyarakat Samin tidak boleh asal berbicara dan jika berbicara harus yang benar (Munawaroh, Ariani, \& Suwarno, 2015).

Angger-angger Pertikel (hukum tindak tanduk), merupakan hukum kedua tentang bagaimana seharusnya perilaku masyarakat Samin yang berdasar kepada: kejujuran, kesabaran, kerukunan, saling menghargai dan dapat memberikan manfaat bagi orang lain. Dengan kata lain masyarakat 
Samin perlu menghindari perilaku seperti srei, dengki, dahwen, nyolong, petil, apus yang artinya perilaku iri hati, dengki, mengaku sesuatu yang bukan miliknya, dan mencuri barang yang bukan miliknya, kikir, dan bersiasat (Munawaroh dkk., 2015).

Angger-angger Lakunana (hukum perihal yang perlu dijalankan), merupakan hukum ketiga tentang pelaksanaan atau tindakan yang seharusnya dilakukan masyarakat Samin setelah memahami kedua hukum sebelumnya yaitu: angger-angger pengucap dan angger-angger pertikel. Hukum ketiga ini berbunyi "lakonan sabar trokal, sabare dieling-eling dan trokale dilakoni (Munawaroh dkk., 2015). Artinya, masyarakat Samin senantiasa diharapkan ingat kesabaran dan ketabahan dalam kehidupan sehari-hari, khususnya dalam menghadapi permasalahan, prinsip kesabaran dan ketabahan dalam menyelesaikan masalah menjadi acuan utamanya. Ini menunjukkan bahwa dalam keadaan apapun masyarakat Samin dituntut untuk tetap berusaha dan berupaya semaksimal mungkin dengan penuh kesabaran dalam mengentaskan permasalahannya serta dapat mencapai tujuan yang diinginkan. Tujuan disini diartikan sebagai tujuan hidup di dunia yaitu senang atau bahagia, baik, rukun, segar, dan sehat, yang kesemuanya ini merupakan hasil samping bagi seseorang yang berhasil menemukan meaning of life.

Kategori meaning of life tinggi berarti bahwa siswa SMP dengan latar belakang budaya Samin mampu meningkatkan keterlibatan diri dalam menjalankan setiap kegiatan berharga dan bermanfaat dengan cara yang kreatif, penuh tanggung jawab, dan tekun. Setiap kegiatan yang dilakukan siswa, selalu diyakini dengan nilai kebenaran, kebajikan, keadilan, keimanan, serta cinta kasih. Apabila mengalami cobaan yang tidak bisa diubah, siswa mampu menyikapi dengan tabah, sabar, dan tetap berusaha menjalaninya. Penjelasan ini sebenarnya jika diklasifikasikan merupakan realisasi dari tiga sumber nilai yang memungkinkan individu menemukan meaning of life, yaitu: creative values (nilai kreatif), experiential values (nilai penghayatan), dan attitudinal values (nilai bersikap).

Frankl (2003) menjelaskan bahwa ketiga sumber nilai memungkinkan individu menemukan meaning of life dengan tiga jalan yang berbeda yakni: (1) melakukan suatu perbuatan; (2) mengalami sebuah nilai; (3) mengalami penderitaan. Jalan pertama adalah dengan berprestasi atau pencapaian, yang dalam ajaran budaya Samin, cara ini tidak dijelaskan secara langsung pada sebuah anggerangger, melainkan sebagai perwujudan dari experiential values yang tertuang pada angger-angger pertikel. Oleh karena itu, hasil penelitian menunjukkan bahwa creative values berada pada urutan ketiga persentasenya setelah attitudinal value dan experiential values.

Jalan kedua adalah dengan mengalami sebuah nilai. Artinya, individu menyerahkan diri kepada kehidupan yang menyiratkan nilai-nilai di antaranya: kebajikan, kebenaran, keadilan, keimanan dan cinta kasih. Frankl menjelaskan cinta kasih dalam arti suatu hubungan pribadi, yaitu dengan seseorang dapat menjadikan orang lain menghayati perasaan berarti dalam hidupnya (Koeswara, 1992). Melalui cinta kasih seseorang dapat melihat potensial orang lain yang dapat dikembangkan atau dapat diaktualisasikan. Apabila dikaitkan dengan ajaran budaya Samin, cinta kasih telah terkandung dalam Angger-angger Pengucap dan Angger-angger Pertikel. Sementara, cinta kasih yang diwujudkan siswa SMP budaya Samin lebih menggambarkan cinta kasih kepada sesama (teman, keluarga), dan cinta kasih kepada alam.

Secara keseluruhan setiap Angger-angger dalam Uri-uri Pambudi didasarkan pada penghayatan akan nilai kehidupan. Oleh karena itu, hal ini sesuai dengan hasil penelitian yang menunjukan bahwa experiential values merupakan kategori tertinggi persentasenya, dibandingkan attitudinal values dan creative values.

Jalan ketiga adalah mendapatkan meaning of life melalui penderitaan. Marliana \& Maslihah (2012), menjelaskan bahwa meaning of life berkaitan dengan ada tidaknya kemampuan individu dalam menyesuaikan diri secara efisien terhadap masalah atau penderitaannya. Dengan kata lain, meaning of life dapat ditemukan dalam penderitaan tergantung bagaimana seseorang melihat dan menyikapinya. Siswa SMP umumnya penuh dengan gejolak emosi (Darmiany, 2016) tapi tidak dengan Siswa SMP dengan latar budaya Samin, hal ini dikarenakan mereka memegang erat ajaran budaya Samin, khususnya dalam Angger-angger Lakunana, mengandung hukum pelaksanaan atau 
tindakan yang mengarahkan untuk sabar dan tabah dalam menjalani kehidupan sehingga mereka lebih tenang dan stabil. Angger-angger Lakunana, juga merupakan perwujudan dari kedua Anggerangger sebelumnya, sehingga berkedudukan tinggi dibanding hukum yang lain.

Frankl menggolongkan attitudinal values sebagai sumber nilai tertinggi (Koeswara, 1992). Artinya, apabila meaning of life dapat terpenuhi melalui realisasi attitudinal values yang tertuang dalam Angger-angger Lakunana, maka secara tidak langsung indvidu sudah menunjukkan keberanian dan kemuliaan dalam menghadapi penderitaan, karena dalam penderitaan tersebut mampu membawa individu dalam pembaharuan moral.

Hasil penelitian menunjukkan bahwa banyak siswa SMP budaya Samin tergolong memiliki attitudinal values tinggi. Sementara, sedikit siswa SMP budaya Samin yang tergolong memiliki attitudinal values sedang. Artinya, hasil ini sesuai karena Angger-angger Lakunana yang memberikan arahan untuk menyikapi penderitaan dengan sabar dan tabah, sementara keberanian dan ikhtiar akan muncul sebagai pembaharuan moral apabila individu mampu merealisasikan attitudinal values secara keseluruhan dikehidupannya.

Inti dari keseluruhan hasil penelitian tentang meaning of life dapat menjadi pijakan awal dalam memberikan layanan kepada siswa terhadap masing-masing bidang: akademik, karier, pribadi dan sosial. Pemberian layanan ini dapat menggunakan pendekatan baik secara etik maupun emik. Pendekatan etik dapat diwujudkan dengan mengembangkan kompetensi profesional konselor. Sedangkan pendekatan emik dapat diwujudkan melalui pengembangan kompetensi personal konselor.

Kompetensi profesional konselor yang pertama adalah memahami secara mendalam siswa yang hendak dilayani. Dengan kata lain, konselor dituntut untuk menghormati dan menghargai keragaman (Radjah, 2016), dalam hal ini memahami nilai-nilai yang dianut siswa SMP budaya Samin. Nilai-nilai tersebut berkaitan dengan pemenuhan meaning of life siswa. Kedua, menyelenggarakan bimbingan dan konseling yang memandirikan dengan memfasilitasi perkembangan siswa pada bidang akademik, karier, pribadi dan sosial. Pada bidang akademik konselor dapat melakukan layanan konseling kelompok. Konseling kelompok membantu siswa agar dapat menjalani perkembangannya dengan lebih lancar dalam arti memberikan dorongan dan motivasi kepada siswa untuk membuat perubahan atau memanfaatkan potensinya secara maksimal sehingga dapat mewujudkan dirinya (Tatiek, 2013). Konseling kelompok memang dikenal manjur untuk memaksimalkan potensi siswa. Konseling kelompok dapat meningkatkan kepercayaan diri siswa (Imro'atun, 2017) serta keterampilan inter personal siswa (Fitriani \& Hidayah, 2016). Konseling kelompok yang diberikan kepada siswa SMP dengan latar belakang budaya Samin, bertujuan untuk menghayati arti belajar dan dikaitkan dengan pengalaman yang dirasa bernilai bagi siswa selama proses belajar di sekolah.

Penghayatan melalui pengalaman yang bernilai selama belajar di sekolah kemudian diarahkan oleh konselor dengan informasi-informasi seputar proses belajar, keefektifan dalam belajar, mencari sumber rujukan, dan menyelesaikan tugas mata pelajaran. Keseluruhan informasi ini dikemas oleh konselor dalam layanan informasi untuk mengembangkan penghayatan siswa dan merealisasikannya dalam tindakan nyata (creative value). Layanan ini juga dikaitkan dengan nilai-nilai tradisi budaya Samin. Sehingga, pencapaian dalam bidang akademik juga dilaksanakan dengan menjunjung nilai kejujuran dan menjauhi sikap malas dalam belajar yang bukan cerminan dari ajaran budaya Samin.

Bidang karier, Super Jung menegaskan bahwa membantu siswa mengembangkan konsep diri positif merupakan bagian dari bimbingan karier di sekolah (Nursalim, 2015). Oleh karena itu, konselor dapat memberikan layanan konseling kelompok dengan mendorong siswa menghayati potensi di dalam diri maupun antar teman, menghayati pekerjaan yang dilakukan orang tuanya, dan tugas-tugas sekolah yang dikerjakannya, apakah sudah sesuai dengan nilai-nilai ajaran budaya Samin dalam rangka pemenuhan meaning of life. Dengan terpenuhinya meaning of life dalam diri siswa maka setiap kegiatan yang dilakukan siswa akan terarah, baik tujuan jangka pendek, maupun jangka panjang. 
Bidang pribadi merupakan komponen layanan bimbingan yang secara khusus dirancang untuk membantu siswa menangani atau memecahkan masalah-masalah pribadi. Bidang sosial adalah bentuk layanan bimbingan dan konseling yang diarahkan untuk membantu peserta didik menangani berbagai masalah sosial atau masalah yang muncul dalam hubungannya dengan orang lain (Nursalim, 2015). Oleh karena itu, konselor dapat memberikan layanan konseling kelompok untuk meningkatkan komitmen diri siswa SMP dengan latar belakang budaya Samin. Komitmen siswa ini diarahkan dalam menghayati nilai-nilai kebajikan dengan mengutamakan kebermanfaat bagi diri dan sesama dan mencapai kerukunan, tenggang rasa yang diyakini sebagai surga dunia bagi siswa SMP dengan latar belakang budaya Samin. Harapannya, siswa SMP dengan latar belakang budaya Samin mampu berkembang menjadi pribadi yang dapat memahami dirinya dan orang lain, khususnya dalam konteks budaya yang berbeda. Sehingga, hubungan sosial dengan teman di sekolah juga terwujud secara rukun, tenggang rasa dan harmonis.

Ketiga, menguasai landasan teoritis bimbingan dan konseling. Langkah awal yang dapat dilakukan adalah mengaplikasikan dasar-dasar layanan bimbingan dan konseling yang sesuai dengan kondisi siswa SMP budaya Samin, khususnya berkaitan dengan ajaran Serat Uri-uri Pambudi yang berisi tiga Angger-angger. Angger-angger pengucap adalah hukum yang mengatur bagaimana siswa bertutur kata. Kandungan nilai dalam Angger-angger ini dapat menjadi dasar agar proses bimbingan dan konseling didasari dengan kejujuran baik konselor maupun konseli, menjunjung rasa kepercayaan, saling menghargai nilai dan keyakinan masing-masing, menjaga hubungan baik selama proses dengan mengedepankan komunikasi yang baik tanpa menyinggung bahkan menyakiti hati konseli maupun sebaliknya.

Angger-angger Pertikel adalah hukum yang mengatur bagaimana siswa dalam bertingkah laku. Kandungan nilai dalam Angger-angger ini dapat menjadi dasar agar proses bimbingan dan konseling menjunjung hak masing-masing, mengetahui peran dari konseli maupun konselor, menghargai dan menghormati keyakinan masing-masing, melihat keunikan dan potensi konseli, serta membina sekaligus menjaga hubungan baik di awal hingga di akhir layanan bimbingan dan konseling.

Angger-angger Lakunana adalah hukum pelaksanaan. Kandungan nilai dalam Angger-angger ini dapat menjadi dasar agar proses bimbingan dan konseling didasari dengan keyakinan bahwa konseli mampu mengentaskan permasalahannya, menumbuhkan sikap sabar dalam setiap proses kehidupan, dan keberanian dalam menghadapi segala cobaan yang dialaminya.

Keempat, mengembangkan profesionalitas sebagai konselor secara berkelanjutan. Pengembangan profesionalitas berkaitan dengan diri konselor dengan pengembangan diri untuk meningkatkan layanan bimbingan dan konseling. Upaya yang dapat dilakukan konselor adalah menambah wawasan dengan mengikuti seminar, workshop dan pelatihan yang berkaitan dengan konseling multibudaya. Hal ini karena pemahaman dalam ranah multibudaya memengaruhi cara berpikir seseorang (Setyaputri, 2017). Harapannya, kompetensi baik personal maupun profesional pada konselor dapat berkembang. Berkaitan dengan kompetensi personal, Carl Rogers memaparkan tiga karakteristik yang perlu dimiliki konselor dalam memberikan layanan bimbingan dan konseling (Jones, 2011). Kompetensi ini dinilai cocok sebagai dasar bimbingan dan konseling pada konteks multibudaya. Kompetensi yang dipaparkan terdiri dari 3 karakteristik yaitu: (1) congruence; (2) unconditional positive regard; dan (3) empathy.

Congruence dapat diwujudkan dengan meyakini dan menjunjung tinggi nilai kejujuran antara konselor-konseli, sehingga keterbukaan dan kepercayaan dapat mencapai tujuan layanan bimbingan dan konseling yang diharapkan. Unconditional positive regard artinya konselor harus mampu memahami dan menerima perbedaan budaya yang ada. Dengan begitu, konselor akan mampu melihat dan menghargai tanpa bersyarat pada konselinya, terlepas dari sudut pandang budaya masing-masing. 
Emphaty dalam diri konselor mengacu pada pemahaman siswa yang mengutamakan pendalaman dan penghayatan nilai kehidupan, namun konselor tetap sadar bahwa merealisasikan nilai-nilai kehidupan yang dihayati siswa tersebut juga tidak kalah penting. Sehingga harapannya, layanan bimbingan dan konseling dapat mengembangkan segala aspek pada diri siswa SMP dengan latar belakang budaya Samin, yaitu: akademik, karier, pribadi dan sosial.

\section{SIMPULAN}

Meaning of life siswa SMP dengan latar belakang budaya Samin tergolong tinggi dengan persentase sebesar 91.7\%. Meaning of life tinggi mengandung makna bahwa siswa SMP dengan latar belakang budaya Samin mampu meningkatkan keterlibatan diri dalam menjalankan setiap kegiatan berharga dan bermanfaat dengan cara yang kreatif, penuh tanggung jawab, dan tekun. Setiap kegiatan yang dilakukan, selalu diyakini dengan nilai kebenaran, kebajikan, keadilan, keimanan, serta cinta kasih. Apabila siswa mengalami cobaan yang tidak bisa diubah, ia mampu menyikapinya dengan tabah, sabar dan tetap berusaha dalam menjalaninya. Dengan kata lain meaning of life siswa memengaruhi bagaimana siswa berpikir, merasa, bertingkahlaku, dan menentukan jalan hidupnya.

Kandungan nilai dalam budaya Samin yakni pada Serat Uri-uri Pambudi dapat digolongkan ke dalam sumber nilai yang memungkinkan pemenuhan meaning of life. Creative values terkandung pada wujud dari Angger-angger Pertikel. Nilai penghayatan terkandung pada Angger-angger Pengucap dan Angger-angger Pertikel, sedangkan nilai bersikap terkandung pada Angger-angger Lakunana. Sumber nilai dengan persentase tertinggi adalah experiential values (45\%), kemudian attitudinal values $(29 \%)$ dan creative values $(26 \%)$. Experiential values menduduki persentase pertama karena dalam budaya Samin mengutamakan penghayatan dengan hati nurani akan nilainilai kehidupan sebelum bertindak (creative values) maupun menyikapi segala sesuatu (attitudinal values). Oleh karena itu, pemahaman meaning of life siswa penting dipahami dalam kandungan nilai pada setiap ajaran budaya. Pemahaman ini dapat diwujudkan dengan memberikan layanan bimbingan dan konseling, khususnya pada layanan konseling melalui pendekatan emik dan etik. Konselor juga dapat mengembangkan kompetensi personal dan profesional sesuai dengan meaning of life dalam konteks budaya siswa.

\section{DAFTAR RUJUKAN}

Alfian, I. N., \& Suminar, D. R. (1999). Perbedaan Tingkat Kebermaknaan Hidup Remaja Akhir pada Berbagai Status Identitas Ego dengan Jenis Kelamin Sebagai Kovariabel (Penelitian Terhadap Mahasiswa Madura di Surabaya). Insan Media Psikologi, 5(2), 87-109. Diambil dari http:// www.journal.unair.ac.id/filerPDF/02 Ilham, Perbedaan Tingkat Kebermaknaan Hidup Remaja Akhir.pdf

Bastaman, H. D. (2005). Integrasi Psikologi dengan Islam: Menuju Psikologi Islami. Pustaka Pelajar Yogyakarta bekerjasama dengan Yayasan Insan Kamil.

Boeree, G. C. (2010). Personality Theories-Melacak Kepribadian Anda Bersama Psikolog Dunia. Yogjakarta: Primasophie.

Darmiany, A. (2016). Pengembangan Model Pelatihan Soft-Skills pada Siswa Sekolah Menengah Pertama Negeri (SMPN) di Kota Mataram. Jurnal Kajian Bimbingan dan Konseling, 1(2), 4754. http://dx.doi.org/10.17977/um001v1i22016p047

Fitriani, M., \& Hidayah, N. (2016). Keefektifan Konseling Kelompok Adler untuk Meningkatkan Keterampilan Interpersonal Siswa SMP. Jurnal Kajian Bimbingan dan Konseling, 1(2), 7-11. http://dx.doi.org/10.17977/um001v1i12016p007

Frankl, V. E. (2003). Logoterapi Terapi Psikologi Melalui Pemaknaan Eksistensi. Yogyakarta. Kreasi Wacana.

Ghozali, I. (2011). Aplikasi Analisis Multivariate Dengan Program IBM dan SPSS. In Aplikasi Analisis Multivariate dengan Program IBM SPSS 19. 
Imro'atun, S. (2017). Keefektifan Layanan Konseling Kelompok untuk Meningkatkan Kepercayaan Diri Siswa Sekolah Menengah Pertama. Jurnal Kajian Bimbingan dan Konseling, 2(2), 50-57. http://dx.doi.org/10.17977/um001v2i22017p050

Jones, R. N. (2011). Teori dan Praktik Konseling dan Terapi. Yogyakarta: Pustaka Pelajar.

Koeswara, E. (1992). Logoterapi Psikoterapi Viktor Frankl. Kanisius.

Marliana, S., \& Maslihah, S. (2012). Analisis Sumber-Sumber Kebermaknaan Hidup Narapidana yang Menjalani Hukuman Seumur Hidup. Jurnal Psikologi, 11(1), 12. http://dx.doi.org/10.14710/ JPU.11.1.12

Masri, S., \& Effendi, S. (2012). Metode Penelitian Survei. Jakarta. LP3ES.

Munawaroh, S., Ariani, C., \& Suwarno, S. (2015). Etnografi Masyarakat Samin di Bojonegoro: Potret Masyarakat Samin dalam Memaknai Hidup. Balai Pelestarian Nilai Budaya (BPNB) Yogyakarta.

Ningsih, Y. M. C. R., Hidayah, N., \& Lasan, B. B. (2017). Studi Meaning of Life Siswa Sekolah Menengah Pertama Etnis Tengger. Jurnal Kajian Bimbingan dan Konseling, 2(2), 76-85. http:// dx.doi.org/10.17977/um001v2i22017p076

Nursalim, M. (2015). Pengembangan Profesi Bimbingan \& Konseling. Jakarta: Erlangga.

Putri, P. S. (2009). Makna Hidup pada Perempuan Dewasa yang Berperan Ganda. Jurnal Psikologi, 7(2), 43-51. Diambil dari http://ejurnal.esaunggul.ac.id/index.php/Psi/article/view/84

Radjah, C. L. (2016). Keterampilan Konseling Berbasis Metakognisi. Jurnal Kajian Bimbingan dan Konseling, 1(3), 90-94. http://dx.doi.org/10.17977/um001v1i32016p090

Rohmah, N. (2011). Studi Deskriptif tentang Tingkat Kebermaknaan Hidup Lansia yang Tinggal di Unit Rehabilitasi Sosial Wening Wardoyo Ungaran. (Disertasi tidak diterbitkan) Universitas Negeri Semarang.

Setyaputri, N. Y.(2017). Karakter Ideal Konselor Multibudaya Berdasarkan Nilai Luhur Semar. Jurnal Kajian Bimbingan dan Konseling, 2(2), 58-65. http://dx.doi.org/10.17977/um001v2i22017p058

Setyarini, R., \& Atamimi, N. (2011). Self-Esteem dan Makna Hidup pada Pensiunan Pegawai Negeri Sipil (PNS). Jurnal Psikologi, 38(2), 176-184. http://dx.doi.org/10.22146/JPSI.7651

Sugiyono. (2006). Statistika untuk Penelitian. Bandung: CV. Alfabeta.

Sukardi. (2003). Metodologi Penelitian Pendidikan. Jakarta: Bumi Aksara.

Sumanto, S. (2006). Kajian Psikologis Kebermaknaan Hidup. Buletin Psikologi, 14(2). http://dx.doi. org/10.22146/bpsi.7490

Syam, N. (2007). Antropologi. PT LKiS Pelangi Aksara.

Tatiek, R. (2013). Teori dan Praktek Bimbingan Kelompok. Malang: Universitas Negeri Malang. 